Article

\title{
The Rise of Calvinist Christianity in Urbanising China
}

\section{Jie Kang}

Department of Religious Diversity, Max Planck Institute for the Study of Religious and Ethnic Diversity, 37073 Goettingen, Germany; Kang@mmg.mpg.de

Received: 28 May 2019; Accepted: 11 August 2019; Published: 15 August 2019

check for updates

\begin{abstract}
Over the past decade, Reformed Christianity, broadly based on the theology of Calvinism, has spread widely in China, especially by appealing to Chinese 'intellectuals' who constitute most of the house church leaders in urban areas. It draws its moral guidance from a so-called rational or intellectual focus on biblical theology, reinforced by theological training in special seminaries. It consequently rejects the 'heresy' of the older Pentecostal Christianity, with its emphasis on charisma, miracles, and theology based on emotional 'feeling'. This Reformed theology and its further elaboration have been introduced into China in two main ways. The first is through overseas Chinese, especially via theological seminaries in Singapore, Malaysia, and Indonesia. For instance, preachings of the famous Reformed pastor Stephen Tong (唐崇荣) have been widely disseminated online and among Chinese Christians. Second, Korean missionaries have established theological seminaries mainly in cities in northern China. This has resulted in more and more Chinese church leaders becoming advocates of Calvinism and converting their churches to Reformed status. This paper asks why Calvinism attracts Chinese Christians, what Calvinism means for the so-called house churches of a Christian community in a northern Chinese city, and what kinds of change the importation of Reformed theology has brought to Chinese house churches. Various significant accounts have addressed this development in China generally. My analysis complements these accounts by focusing on a small number of interconnected house churches in one city, and uses this case study to highlight interpersonal and organizational issues arising from the Calvinist approach.
\end{abstract}

Keywords: Christianity; Reformed church; Calvinism; urbanization; theology; China

\section{Introduction}

Over the past decade, Reformed Christianity broadly based on the theology of Calvinism has spread widely in China (Brown 2009; Chow 2014a, 2014b). Descriptions of Calvinism vary greatly, often according to context. The flourishing of Chinese Calvinism has drawn the attention of the media and scholars (Brown 2009; Chow 2014a, 2014b; Chow 2018, pp. 97-114; Fällman 2009, 2012; Ma and Li 2018, p. 120; Fulton 2015, p. 37).

This paper views Calvinism from a Chinese perspective in the context of modern China, especially the country's rapid urbanisation. Calvinist theology is often associated with the process of urbanisation. It is claimed that European Calvinism thrived in cities and so constituted an urban ideology (Kingdon and Linder 1970, p. xi). This may stem from the positive early support that Jean Calvin received from such cities as Basel, Strasbourg, and Geneva and other urban areas. How does this claim compare with Calvinism in Chinese cities?

Chinese Calvinism is indeed urban, insofar as it draws on urban educational and literacy levels, which are higher than those found in rural areas. However, Berger (2013) observes that Pentecostalism has also spread worldwide under urban conditions, especially in Latin America and Africa. In China, a mainly rural, Pentecostal-like form of Christianity (not, however, identified as Pentecostal by 
believers) involves speaking in tongues, presenting 'miracles', and emphasising emotional expression (Kang 2016). But it has not taken root in the cities. Rather, it is a form of Calvinism which is thriving in China's megacities and other urban areas.

It is true that both forms of Christianity seek the betterment and self-advancement of individual believers, including enhanced education, especially for children. They also both emphasise the high importance of community interaction, care for the family, and personal welfare. But urban Calvinism has forcefully rejected the rural Pentecostal-like counterpart, with urban believers valuing education above what they regard as rural 'superstition', which to them is incompatible with China's march towards so-called modernisation and technological supremacy. Since this urban-based 'progress' is seen as male dominated, the contrast between the two forms of Christianity is also gendered.

In Pentecostalism, women are the most active and expressive members of the congregation and are the power behind the few male church leaders. In the Chinese Calvinist churches, however, men provide the disciplinary drive at all levels. They impose strict rules about learning doctrine and seeking 'truth', and are the prime judges of theological correctness and church morality. Women are less prominent, expected to play roles as helpers and assistants in church and family.

Rapid and extensive urbanisation in China, the country's extraordinary technological, educational, and politico-economic international rise, and the work and personal discipline needed to achieve it within a few decades have filtered down to its population, including its urban Christians whose turn to Calvinism reflects this advance, which is commonly seen as largely led by men.

Some believers claim that their Christianity is a distinctive form of 'Calvinism with Chinese characteristics' $^{1}$. This raises the question of how similar or otherwise are Chinese and European Calvinism. Many religious movements worldwide claim to be Calvinist and use this label to identify themselves as either different from or as allied with others. When we look at individual cases of groups calling themselves Calvinist, we often find that their differences of belief and practice are shaped by the different contexts in which they occur. Given the crucial importance of these varying contexts-in China's case, its rapid urban population growth-this paper is therefore opposed to beginning analysis of Chinese Calvinism from an intrinsically religious viewpoint and starts, instead, from the interaction of its practitioners with the specific circumstances of China's Christian history.

In the late nineteenth and early twentieth centuries, Western missionaries set up Presbyterian churches in parts of China. In some, such as Fujian Province, they may still have some influence. However, what we may call the recent or New Calvinist wave has developed largely independently of this early Western form of Reformed Christianity. The new wave of Reformed theology, or Calvinism, was introduced into China through two channels. The first is overseas Chinese, especially via theological seminaries in Singapore, Malaysia, and Indonesia. For instance, preachings of the famous Reformed pastor Stephen Tong (唐崇荣) have been widely disseminated online among Chinese Christians. Second, Calvinist theology has been introduced by Korean missionaries who have established theological seminaries mainly in cities in North China. This has resulted in more and more Chinese church leaders becoming proponents of Calvinism and converting their churches to Reformed status. My research focuses on the latter.

Associated with China's extensive urbanisation is the rise of modern Chinese intellectuals with urban-produced aspirations of literacy and modernity. For such intellectual Christian leaders, the evolving Chinese version of Calvinism is much more sophisticated than other, usually earlier and rural, forms of Christianity, which depend less on literacy and the use of key texts. Calvinist theology meets their demands by providing a comprehensive understanding and interpretation of doctrine, a large amount of literature on how to practice Christianity in everyday life, a well-structured belief system, and a systematic, Presbyterian-like method of organising and governing churches.

1 The term "... with Chinese characteristics" is widely used to refer to the unique institutions or practices of Calvinism in China, thus distinguishing it from Calvinism elsewhere. 
Unlike most published work on Chinese Calvinism, which highlights public intellectuals and politically high-profile elites (e.g., Chow 2014a, 2018; Fällman 2012), this paper focuses on a grass-roots and low-profile community in what I will call City $\mathrm{A}^{2}$ in North China and its Pastor Liu, and analyses through case material how a distinctively Chinese form of Calvinism is shaped by its dissemination in China through global connections. The Chinese Calvinist primacy placed on 'rational' or 'intellectual' theologically-based belief does not necessarily mean that the faith is spread only by church leaders regarded as public intellectuals. Indeed, although Alexander Chow (Chow 2014a) attributes the spread of Christianity to the role of public intellectuals-including students and activists, some of whom are linked to those involved in the Tiananmen Square movement of 1989 and so have implicitly challenged the government-he concedes that such people are a very small minority of the Christian population. Fredrik Fällman's research is also based on Chinese Christians who are public intellectual elites, like the writer and critic Yu Jie and the bestselling author Bei Cun, and the politically high-profile congregation Fangzhou (the Ark) in Beijing. He also claims that, among such public intellectuals, "major actors here are overseas Chinese and Mainland exiles" (Fällman 2012, p. 157). Notwithstanding the possible indirect influence of domestic and overseas public intellectuals' ideas, the house churches I have studied in North China are neither led by public intellectuals nor, as far as I can tell from first-hand observation, directly influenced by them, even though these churches emphasize the importance of basing their belief on what they call a 'rational' and 'intellectual' theology.

It is true that urban house churches are generally led mostly by educated church leaders, but very few can be called public intellectuals, as distinct from having a view of their work as requiring an intellectual perspective. I would modify Fällman's observation and would instead claim that the major factor in the spread of Calvinist theology is the grass-roots Christian network in mainland China, and that this supersedes the influence of overseas Chinese or politically high-profile public intellectuals. It is precisely because of the low profile resulting from their discreetly dispersed yet expanding network gives them that Christian house churches do not normally attract the attention of media or government and so can grow quietly and quickly.

For many people who migrate to, or spend their lives in, urban areas, Calvinist churches provide not only a community-like surrogate family, but also a 'life system' that offers clear answers for everyday problems arising from marriage, parenting, work, and self-development. These issues used to be the responsibility of the Communist Party's danwei (work units) before 1979, or of families in villages. But now, there are no urban institutions catering to such problems. Let me now describe in more detail the activities of, and influences on, Chinese Calvinism.

The method of empirical observation in the fieldwork on which this paper is based is that of anthropological participant observation, and both structured and unstructured interviews, during various periods of a few months each over ten years. For reasons of anonymity, the particular areas of study are not given but are in northern China. The church chosen for the study is part of a huge network based on a theological seminary which is very influential in northern China. The aim of this article is to focus on a case of Chinese Calvinism but not to do a comparison of other forms of Calvinism within or outside China.

\section{Case Study}

In September 2017, a remarkable event happened in the expanding modern history of international Christianity. A group of Chinese Christian pastors made a pilgrimage to Germany, where Martin Luther lived and proclaimed his Ninety-Five Theses, so founding the Protestant Reformation, which spread across the world and is now very important in China. The event is remarkable because the group of Chinese pastors did not just visit these places as shrines. They used the occasion to reflect deeply on Christianity in the world and on the future role of a newly emerging and distinctive Chinese Calvinism.

2 For reasons of anonymity, the city's name is not disclosed. 
This distinctiveness is evident in the four reasons for this trip, summarised by the delegation's head, Pastor Liu:

1. To get a deeper understanding of the Christian Reformation by visiting the birth- and workplaces of Martin Luther and John Calvin.

2. To try to understand why Christianity in modern Europe appears to have undergone a decline. (In Pastor Liu's words, a 'degeneration' [阷落 duoluo]. His conclusion is that 'theological liberalism' is to blame, especially in Germany, regarded as the stronghold of liberal theology. The implication is that Chinese Calvinism has the discipline to resist such decline.)

3. To observe the development of Islamisation in Europe, especially since the entry of a large number of refugees from Islamic countries beginning in 2015, and to see whether it has been accelerated by this influx.

4. To establish contact with Chinese Christian organisations and churches in Europe, in order to support and facilitate their help for each other. (Pastor Liu was interested in sending short-term missionaries to Chinese churches in Germany.)

Pastor Liu is the leader of the Gospel Church in City A, having been ordained in 2011. I first met him in autumn 2006. Since 2005, he had been studying at the Grace Theological Seminary (otherwise known as the Korean Calvinist Theological Seminary) and managing the church, spending three months in the seminary and then carrying out shepherding tasks for three months within the church. He did this for four years. By 2008, the Gospel Church had about three hundred followers in six gathering places (聚会点 jühui dian) in City A; but in 2003, when Pastor Liu took over its leadership, it had only fifty-seven members. He described the church's development as follows:

"The church was founded in 1990 by Brother Zhi, who worked in tourism and often hosted foreign Christians. He had contact with American churches. They were Pentecostal. They offered Brother Zhi 2000 RMB a month, and he rented an apartment in City A for gatherings. The place became a tourist spot for American groups, who came here to worship and at the same time visit this Chinese house church. I came to the church in October 1999. At that time, the church was open to everyone. Foreigners could preach in the church if they wanted to do so. When there were no foreigners to preach, we ourselves could all do so, for everybody was allowed to preach. There was no theology. The pulpit of the church was chaotic [讲台很混乱 jiangtai hen hunluan]. Provided you were Christian, you were allowed to preach. Even people from Eastern Lightning [东方闪电 dongfang shandian] could preach. Nobody felt there was anything wrong about this. Even someone suffering from a mental disorder could preach. During a holiday on 1 October 2002, a pastor from the United States preached and, for some days, led the church in dancing and singing loudly. A neighbour reported this to the police, who came, banned the church and dispersed the church members. At the time, we had three gathering places, but we closed them out of fear. Instead, we separated into six small, inconspicuous groups [小组 xiaozu]. At the 2003 Spring Festival, we had a meeting of six co-workers, three of whom composed a letter accusing Brother Zhi. Their main objection was that Brother Zhi put the church in danger by keeping in regular contact with foreigners, which the government was strictly opposed to and would watch for. In receiving one foreign group after another, Brother Zhi was regarded as having made things impossible in City A. But Brother Zhi's vision was to 'entertain strangers,' and so he agreed to leave the church, whereupon the co-workers then recommended and elected [推选 tuixuan] me as convener [召集人 zhaoji ren]. From then until now [March 2010], we have had no major split in the church. In October 2003, the retreat meeting of the entire church had fifty-seven people." ${ }^{3}$ 
This interview took place in 2010, at which time the church had four hundred members. In 2017 it had about one thousand. Following Pastor Liu's description in the interview, we can see that the procedural style of the church prior to 2003 was quite free and seemingly egalitarian, with anyone entitled to preach at will. This situation changed completely after Pastor Liu started studying in the theological seminary. Calvinists generally regard the pulpit as holy and allow only properly theologically-trained people to preach. I was told that the sermon delivered from the church's front area represents the words of God and therefore has great power, and it is certainly no longer the case that just anyone is entitled to preach at the pulpit. The entitlement to preach, zhan jiangtai (站讲台), has become more and more limited and the actual preaching made more demanding. At the same time, its limited accessibility has given it greater value and made it more and more desired by many male Christians for the honour it bestows, since it means recognition by churchgoers and achievement within the Christian circle. While there were no special requirements earlier to preach in the church, years of training are now needed to be regarded as able to zhan jiangtai. The former style was quite common among Chinese house churches in the past, supported by the understanding that everyone is equal and therefore has the right to talk about his or her belief in front of other Christians.

In describing the earlier form of church organisation as 'chaotic' (混乱 hunluan), Pastor Liu and other Gospel Church Christians convey two senses of the term: The absence of theology or a 'rational' concept of biblical truth, and the absence of a clear organisational structure in the church.

\section{A Concept of Biblical Truth}

The house church adherents did not begin with their belief based on a concept of biblical truth or knowledge of theology (对真理不清楚 dui zhenli bu qingchu). In fact, as I have indicated elsewhere (Kang 2016), the traditional Chinese house churches that I have observed previously tended to be 'anti-intellectual' and to reject theology in favour of charismatic leadership and the performance of miracles. The first task for Pastor Liu was to change this aspect of the Gospel Church. From 2006, he gave a series of sermons focusing on the importance and necessity of theology. As a result, the whole church changed. Younger believers, in particular, did not relate to the traditional Chinese Christian beliefs and so fully supported Pastor Liu and were eager to study theology themselves. Studying in a seminary is regarded as only for those who are committed to God's calling and to being a full-time servant (全职侍奉 quanzhi shifeng). For most congregants, the Gospel Church offers courses according to level of belief and church commitment. For instance, 'disciple training' is for those who have shown commitment to the church for more than three years and are regarded as potential group leaders, missionaries, or preachers. This challenging training is led once a week, by Pastor Liu himself, and usually lasts two years. The second level of training is a short but intensive program aimed at producing Sunday school teachers or imparting evangelising skills. Recently, the Gospel Church set up a one-year theological training and catechism class, and so now covers a range of training possibilities.

Each Sunday worship includes a sermon at least forty minutes long. Weekly Bible study among small groups of co-workers focuses on the Westminster Shorter Catechism and the Heidelberg Catechism. The church is thus something of an educational institution, with training and learning regarded as essential, not only for conveying biblical truth, but also for building a community of members within the church. They study together, share their thoughts with each other and, in their own words, "grow together". Moreover, Pastor Liu sees himself as having taught believers how to distinguish what he sees as heterodoxy or heresy from true belief. He puts such other beliefs into three broad classes or levels.

First, there are religions that he identifies as paganism (异教 yijiao): “With regard to such other religions, including Buddhism, we respect and understand them as culture. However, we also believe that they are paganism and used by Satan to delude people. I once asked a church member what he thought of Buddhists. He said, 'What do you think of them? Of course, they are possessed by evil spirits'." This attitude of some years ago has been extended to Islam over the past five years. 
Second, there is “heresy" (异端 yiduan), as instanced by the sect named Eastern Lightning (东方闪电 dongfang shandian) and the so-called Shouters (呼喊派 huhan pai). Their practices are regarded as based on false beliefs, and they must be watched and kept at arm's length, in order to prevent hidden heretics who pretend to be Christian from splitting the church-in fact, the Gospel Church takes particular care to keep an eye on such so-called heresy. Thus, any church member judged to be a heretic must immediately abandon their heretical belief and follow only the teaching of the Gospel Church, or be expelled.

Third, there are extreme cases of churches (极端 jiduan) whose focus on the Holy Spirit extends to speaking in tongues and working through spiritual dreams and healing and/or emotional expression, especially weeping. Those who used to speak in tongues have now stopped doing so in Chinese Reformed churches. 'Pentecostalism' is, in this way, generally subject to Calvinist criticism.

Overall, there is a clear push for individual church members' beliefs to be more integrated into a collective 'understanding' of the Bible, with the community of believers itself becoming more exclusive. According to Brother Su, a group leader of the Gospel Church, "Through learning, brothers and sisters understand biblical truth more clearly. Therefore, we are able to distinguish and identify heretical beliefs and evil doctrines [异端邪说 yi duan xie shuo] and not be plundered by them. Now we are all of one mind to build our church." This unity and uniformity of belief is seen as achieved through years of learning and studying. Brother Su continued, "Building the church on the biblical truth is very important, because people coming from heresy often come and encroach on the church. Recently, two of them came to our church. At the beginning we didn't recognize them. But soon they started expressing their opinions on WeChat, acting as great counsellors and leaders of this generation, claiming that to believe only in Jesus is not enough to be saved. I have kicked them out of our WeChat group [微信群 weixin qun]. They are very dangerous, since they are familiar with the Bible and often use citations from it. If our church members were not clear about the biblical truth, some would not agree with my action in kicking the heretics out. But now we have reached a consensus." 4

\section{Calvinism with Chinese Characteristics}

Worldwide Calvinism has taken various forms ${ }^{5}$. Yet in discussion and definitions of Calvinism, it is not always clear what the term refers to. What kind of Calvinism does a community identify with, and what doctrinal features does it prioritize? As regards Chinese Calvinism, these questions can be answered only through the interpretations of Reformed church leaders and followers. There are broadly four such aspects.

\subsection{Attitude towards the Authority of the Chinese State}

The attitude of churches towards current political authority is always a controversial topic among Calvinist theologians. Andrew Brown (Brown 2009) suggests that Chinese church leaders use Calvinism as the basis of a theology of resistance to government. By contrast, the churches I have studied regard the Chinese Communist Party (CCP) government as God-given and therefore legitimate. They therefore do not oppose the authorities and do keep a distance from government. Chinese Calvinism is therefore not entirely homogeneous, but varies to the extent that churches follow political or evangelical directions. Churches do, however, have in common a similar internal authority system based on theology, morality, and obedience.

$4 \quad$ Telephone interview on 17 April 2017.

5 It should here be noted that Chinese Calvinism differs in some respects from that described by Hansen (2008) in his book "Young, restless and Reformed" about new Calvinists in the USA and some other parts of the world. For instance, the American style of preaching is depicted as exuberant compared with the more solemn Chinese style, and its churches more inclusive of other kinds of Christians compared with Chinese churches' exclusion of other denominations, especially Pentecostal. Secondly, American Calvinists emphasize 'happiness' as a major goal and not just the observance of doctrine, which is a priority for the Chinese. Comparison of such different forms of Calvinism would make an interesting but much larger project which is, however, beyond the aims of this particular study, which focuses on Chinese Calvinism. 
Pastor Liu distinguishes between two types of Calvinist church at present. One focuses on what he calls a cultural mandate (文化使命 wenhua shiming), with church leaders primarily interested in addressing political and social issues. He gives the example of Pastor Wang Yi, who was well known in China as a human rights lawyer and influential public intellectual. The second kind focuses on what Pastor Liu calls its evangelising mandate (福音使命 fuyin shiming), concentrating not on olitical activities but on spreading the gospel in China and abroad, especially among Muslims. This is the mission of Pastor Liu's own Gospel Church, in contrast to Chinese Reformed churches whose cultural mandate is to try to directly influence Chinese society by changing the sociopolitical climate.

In fact, some leaders of the second kind of Calvinist church identified by Liu claim that the best way to spread Christianity is not by challenging government on religious freedom in the wider political sense, but by keeping a low profile and staying underground. This necessitates small numbers of believers meeting in inconspicuous, small house churches, which Liu claims gives them the warm feeling of being surrounded by a small group of family members. It also facilitates a sense of belonging. Gospel Church members also avowed that dividing into small groups and meeting in different believers' households prepares them for any government crackdown on Christianity. They may be unable to have large meetings, but by being well-connected through these small groups or cells, they can remain active. They also take the view that being low-profile and rejecting visibly higher status can purify congregants and filter out those who do not truly believe. Confrontation with government is thus rendered unnecessary and, moreover, they believe that the authority of the Party and the government is given by God and therefore justified. According to Pastor Liu and his church members, the most effective way of changing the government's attitude towards Christianity is to pray for it.

Their major 'worldly' concern is, in fact, the influence of Islam, which they aim to stem by converting Muslims to Christianity. Because they avoid overt opposition to government and prefer to remain relatively hidden from the gaze of the authorities, changing government policy is not part of what they see as being their concern through God. On the contrary, Pastor Liu and his church network support the government in many ways. For example, news regarding government policy that controls Muslim activities is often posted in the Christian WeChat group. However, news of government destruction of church buildings is not reported. It is only in reading WeChat groups' discussions that one might form the impression that the Chinese government, in effect, supports Chinese Christian missionary work, through its policy of strict surveillance of Muslims. Various news reports of government opposition to radicalized Islam are interpreted by Christians as pointing to the fact that, unintentionally, government and Christianity share the aim of diminishing Islam.

\subsection{Rational Urban Theology Contrasted with Feeling-Based Christianity in Rural China}

I have illustrated in detail elsewhere (Kang 2016) how the rural-rooted house church has changed from emotional, feeling-based practice to an urban, rationalized form. The turn to Chinese Calvinism is certainly part of this transformation, in which feeling-based practice is discouraged and systematic theology becomes not only appealing, but also absolutely necessary.

At first sight, there appears to be some continuity of Confucian influence in modern Chinese Christianity, especially in its form of Calvinism, as for example its inherent authoritarianism. But there is no evidence for such direct influence in modern Chinese Christianity. It is true that early Christian converts were Confucian scholars during the Ming and Qing dynasties when Confucianism was the official ideology. Confucianism has, in fact, lost its influence under pressure from communism, especially the Cultural Revolution of 1966-1976. The massive Christian conversion taking place in urban areas since the 1990s results more from a search for a new moral and belief system aimed at filling the so-called 'spiritual vacuum'. Alongside this development of authoritarianism, the modern transition in China from the Pentecostal-like rural form of Christianity to the urban emphasis on doctrine and institutionalized Calvinism does indicate a rationalization process of disenchantment similar to that described by Weber for Europe. 
Korean Christianity has been regarded as incorporating Confucianism, as with other aspects of Korean society. To the extent that Chinese and Korean Christianity share similarities as a result of Korean missionary influence, this results from the importation into Chinese Christianity of the whole Korean Reformed Christianity package, rather than directly from past Chinese Confucianism.

When I asked Pastor Liu the reason for the popularity of Calvinist theology in China, he said it is because "Calvinism is based on the Bible and has been formed into a total belief system that includes reason, consequences, and action. It is a systematic and complete world view. The life of belief is first of all about the inner self, which then affects one's behaviour or actions. Such belief involves changing one's views of life, the world, and values [i.e., the three views, 三观 sanguan]. This is what the Bible says one must do. Reformed theology comprises the three views conveyed by the Bible and delivers a rational belief system that is very appealing to Chinese intellectuals. This is because intellectuals do not want to believe in a religion that they don't understand. They want to know what it [Christian belief] is and why they should believe in it." ${ }^{\prime \prime}$

While believers at traditional, rural-based churches read only the Bible, Reformed churches in urban China closely follow Christian catechisms or creeds such as the Westminster Catechism, the Heidelberg Catechism, the Westminster Confession of Faith, etc. They often make a public statement of their faith by hanging on the church wall examples of such creeds signed by all the church members or the group leaders of the congregation. Pastor Liu's congregation hangs the Westminster Confession of Faith on the wall at all their meeting places. Instead of studying just the Bible every week, as they once did, Gospel Church members have now studied the Westminster Catechism for three years. Their aim is to unify the church theologically and prevent it from splitting.

However, the turn to Calvinism has had a price. Since it is commonly believed in traditional house churches that the Bible is the only scripture and should be the exclusive focus of study, the addition of catechism caused a great disagreement among church members, especially those who had been leaders in traditional house churches. The dispute often arises over the question of how to understand God's will. For Pastor Liu, this is possible only through learning "the truth" in the doctrine conveyed by catechism, while members from traditional house churches often interpret God's will based on feelings received from God. This is the main reason for the Gospel Church's split.

According Sister Yi, one of the six main church leaders at the Gospel Church, God Himself directly led her on her way, even giving direct instruction in preaching. "God picked many preachers in our church, 'moving' them Himself. We just prayed and read the Bible. We didn't have any reference books or other materials. Everything was taken from the Lord Himself. This was direct guidance by the Holy Spirit. For example, when we prepared some preaching, God would not only give the title of the sermon, he would also reveal the relevant Bible verses which would be interwoven with the preaching. When we kneeled before God, He would just write the entire sermon in our hearts. Even some teachers from a theological seminary admired us. Although we didn't receive any formal theological training, our interpretation of the Bible was acceptable, all of which was taught by the Holy Spirit. We didn't understand theory, but we knew how to practice."

In 2002, Sister Yi came from what I will call City H in North China to City A and joined the Gospel Church. Her viewpoint was in direct contrast to that of Pastor Liu. She complained, "Pastor Liu always claims that I am emotionally oriented [i.e., not 'rational']. But that is not true." Their different views of the necessity of formal or 'rational' biblical teaching for understanding ended up splitting the church, with Sister Yi leaving along with dozens of believers. There was another reason for Sister Yi's departure. She was dedicated to preaching and giving sermons in church, and was regarded as a gifted preacher. But the Reformed church is strictly opposed to women preaching. Sister Yi became upset at co-workers' meetings when the issue of women preachers was raised and declared unacceptable, the rationale being that wives are supposed to be obedient to their husbands. In the past at the Gospel

6 Interview on 22 September 2017 in Germany. 
Church, some co-workers were female, but now almost all are male. Women are expected to help men in the church and the family.

The split was indeed a body blow to the church, but also a watershed in its development. One of the believers who was close to Sister Yi told me sadly, "The major change of the church was the departure of Sister Yi. It was painful to see them [Sister Yi and Pastor Liu] separated and at loggerheads with each other. Sister Yi gave me a lot of love and care. When I had trouble in my life, she was there to comfort me and pray for me. However, before Calvinist theology entered our church, I only pursued the feeling of being moved [感动 gandong], which is kind of egocentric. There was a kind of spiritual arrogance, that I am more spiritual and therefore better than other people. If I did not have the feeling of being moved, I would think of the scene of the crucifixion of Jesus that makes me weep. I felt like I should weep. When I saw the kids at our Sunday school not weeping while watching the movie The Passion of the Christ, I was very angry with them. I could not accept the weakness of other people and lacked mercy, since I didn't realize the nature of sin and relied only on my own efforts. Now I am much clearer through the truth of God and have no doubts as to whether I have been saved by God. My hope is based on God's words, which will never change and which helps me through low periods. I have become more objective and humble. In the past, I only focused on my own spiritual life and didn't have a sense of the kingdom of God, and of the gospel and mission."

\subsection{Hierarchical Church Organisation, Male Authority and Authoritarian Leadership}

It is well known that different definitions of Calvinism may emphasize different aspects. American Calvinism advocates an egalitarian church organisation, unlike Chinese Calvinism's penchant for hierarchy. Lacking this egalitarian approach, and consistent with its avoidance of confrontation with government, Chinese Calvinism does not encourage the introduction of Western democracy in China (though see Niebuhr (1937) for an early discussion of how Christianity in the USA can become involved in politics). Whether or not Calvinism can be regarded as a source of democracy is indeed a controversial question (Kingdon and Linder 1970). Even Calvin himself is a controversial character. Although possibly prejudicial, the worst image of him is presented by the Austrian author Stefan Zweig in his book The Right to Heresy: Castellio against Calvin. Many scenes in this book describe how Calvin took power and incited violence in Catholic churches, so reminding one of the Cultural Revolution in China. It is clear that different kinds of governance, both democratic and authoritarian, can stem from Calvin and Calvinism according to varying social and political circumstances.

We may note here the observation by Gwendolen Carter in her Politics of Inequality that "from the political point of view it is significant that Calvinism is inherently authoritarian ... Where Calvinists have fought for freedom of conscience, it was due to circumstances rather than their theology" (Carter 1958, p. 273). Chinese Calvinist churches are indeed individually and internally run by authoritarian pastors, for, since there is no China-wide Presbyterian-like structure of senators and elders managing the church, they are thus not subject to higher authority and have a great deal of power. The co-workers who take care of the church's everyday activities are personally selected and trained by the pastor. They are loyal to the pastor and follow his or her decisions. Therefore, the pastor's authority is based not on his or her theological knowledge, but, most important, on these personal relationships, which have been strengthened through years of care and training.

Before Calvinism, there was no clear structure of Chinese church leadership. Church co-workers arose 'naturally'. There were no set rules regulating or managing them. Whoever initiated and attended to church activities was entitled to be a church co-worker or leader. Sister Yi, for example, started to preach only forty days after her conversion in 1988. She excitedly spoke of the first time that she was invited to speak before believers at a house church in City H: "One day, Sister Qin [a co-worker in Sister Yi's church] asked me, 'Sister Yi, can you say something?' I was so happy, since I had been longing for it. I said yes. On that day, I really wanted to speak. I felt that I had a lot to say. I had no fear of standing in front of many people. I was full of joy. But my first preaching lasted only ten minutes. I had expected to be given much longer, since I felt I had so much to say. It was my first preaching." 
Sister Yi soon became one of the major co-workers in her church in City $\mathrm{H}$, later retiring early so she could preach full-time. Likewise, as we saw above with Pastor Liu, he was not systematically elected, but rather chosen by the church leaders, informally agreed among six co-workers. Such cases can be found often in other places in China: Church leaders emerge naturally without formal election, in the absence of set standards or procedures, especially in rural areas.

A major criterion conventionally defining a Calvinist church is whether or not it practices Presbyterianism - that is to say, has a structure of government in which elders form the church management (Baugus 2014). The Gospel Church found it extremely difficult to reform its leadership to consist of a plurality of elders and, at the same time, to form a presbytery with other local churches. However, Sister Yi's departure was the first step in facilitating this possibility, for it removed her preference for unstructured leadership. Since then, Calvinist, theologically-based faith has encouraged further development in this direction. The number of church members has increased from five hundred in 2011 to one thousand in 2017, distributed throughout twelve gathering places that all have the same teaching content and management style. To be able to practice Presbyterianism, the church has needed to establish a membership system. This means applying a set of rules to decide who is entitled to be a formal member and who is not. Only those with formal membership have the right to vote for elders. Because some Chinese house churches instead adopt a form of Presbyterianism. Pastor Liu has spent a long time training believers to accept and support the stricter concept that he believes in, but he still cannot achieve the complete transformation of the church. For many Chinese Reformed churches, like the Gospel Church, the Presbyterian structure is an ideal version of organisation that they are trying to reach.

\subsection{Calvinism as a Life System-Obedience and Morality}

A former prime minister of the Netherlands, Abraham Kuyper, presents Calvinism as a life system, a systematic world view comprising three important relationships: Between humans and God, between humans, and between humans and the world (Kuyper 1931, p. 9). To what extent does Chinese Calvinism share this view?

First, Chinese Calvinism differs from the early European version in that its followers are not uncertain about their salvation. Indeed, they are sure that they are saved because they regard their lives as predestined by God alone. When asked whether they are sure of their salvation, they often quote Romans 10:10: "For with the heart man has faith to get righteousness, and with the mouth he says that Jesus is Lord to get salvation." It is thus unlike Weberian Calvinism, in which an individual's salvation is not certain, meaning that he or she must constantly seek the evidence of salvation by working hard and achieving economic success in response to God's calling. Such reassurance is also important for churchgoers in urban China, because it provides them with clarity in dealing with the uncertainties of everyday urban life.

Second, Chinese Calvinist theology emphasises discipline and obedience to pastors, normally without much debate regarding theology or church management. Those who do not support the pastor's theological viewpoint are gradually marginalized and may even leave the church, as the case of Sister Yi shows. The relationship between pastor and main co-workers is similar to that between master and disciples in a traditional Chinese Buddhist temple.

Moreover, because Chinese Calvinist theology encourages hard work for the sake of God and sees no wrongdoing in earning money through Christianity, provided that one-tenth is contributed to church or missionary work, many Christian companies promoting religious tourism have emerged in China. On trips to Israel, Christians visit the birthplace of Jesus and the places where he worked, with the aim of getting a deeper understanding of the Bible. According to one report (Hinsdale 2017), in the first seven months of 2017, sixty-four thousand Chinese travelled to Israel. In the past ten years, Chinese Christian tourist companies have broadened their itineraries to include Turkey, Egypt, Korea, and parts of the Mediterranean where Paul was a missionary, as recounted in the Acts of the Apostles. Chinese Christian tourism thus plays a role in global connectedness and reinforces Christians' beliefs. 
Finally, despite being already saved, Chinese Calvinists are expected to reshape their world view, particularly by reassessing their life and values. There is thus a heavy emphasis on morality and a puritanical way of life. Early European "puritanism" has, in fact, become something of a role model for modern Chinese Calvinists based on a strict doctrine and moral code. In not cultivating an overt political outlook, Chinese Calvinism focuses inwards, on the personal aspects of a moral life such as honesty, obedience, filial piety, and the value of marriage. Church leaders tell their congregations to follow the so-called moral law (道德律 daode lï) of leading a moral and pure life, regarded as gratitude for God's salvation.

Pastor Liu likened this emphasis on morality to the Puritans' insistence on honesty and obedience in sixteenth- and seventeenth-century Europe. The teaching or guidance of moral behaviour stems from the Ten Commandments, which relate people to God. Pastor Liu remarked, however, that the main challenge to Chinese urban churches arises from sexual behaviour, especially premarital sex and extramarital affairs. He sees this as undermining marriage and the family, with Chinese society becoming more and more tolerant and accepting of such 'deviant' behaviour.

\section{Conclusions}

Since its pastor studied at the Korean Calvinist Theological Seminary, the Gospel Church has changed dramatically. First, it has undergone internal reform and external expansion, resulting in a dramatic change of theological approach and organisational structure from those of the previous house churches. In focusing on a 'rational' or 'intellectual' theological doctrine, it rejects 'heresy' and the earlier Pentecostal character of Christianity in China. Second, since there is no China-wide management structure of senators and elders, as in standard Presbyterianism, the individual pastor has much more power than if he were subject to a higher authority. Finally, the Calvinist insistence on engaging with worldly matters without confronting government is evident in the church's drive to peacefully convert Muslims, a goal that unites and motivates church members. Since its split in 2011, the Gospel Church has been growing dramatically, aided by its rejection of heresy and its policy of not confronting the government, both of which appeal to urban Chinese.

Arising out of this conclusion, there is a possible agenda for future research. Thus, while China's rapid urbanisation is bringing about major social changes, there appears to be some continuity with past organisational and behavioural expectations and pressures. We can ask, for instance, how significant is it that modern Chinese Calvinism shares some broad features with early Communism:

(a) religious/ideological emphasis on puritanical morality, such as loyalty to authority (Party, God, church leaders), honesty, and sexual morality;

(b) totalitarian organisational authority of leaders, with churches constituting active, efficient, and flexible cell units (such as Bible study groups) partly echoing the functions of the now defunct Communist danwei;

(c) dependence on a holy script or written dogma;

(d) opposition to liberalism (religious and political, respectively);

(e) potential to be a revolutionary force.

How much does the dissemination of Calvinism depend on this continuity?

Funding: Research was funded by the Max Planck Institute for the Study of Religious and Ethnic Diversity, Goettingen, Germany, where the author is a fellow.

Acknowledgments: The author acknowledges with thanks comments made by Peter van der Veer, Kenneth Dean and participants at the workshop on "Chinese Religions in the Age of Massive Urbanization" on 6-7 of June 2018 at the Max Planck Institute of Religious and Ethnic Diversity, Göttingen, Germany, where the paper was presented.

Conflicts of Interest: The author declares that there is no conflicts of interest. 


\section{References}

Baugus, Bruce P. 2014. Introduction: China, Church Development and Presbyterianism. In China's Reforming Churches: Mission, Polity, and Ministry in the Next Christendom. Edited by Bruce Baugus. Grand Rapids: Reformation Heritage Books, pp. 1-23.

Berger, Peter. 2013. Peter Berger on the Explosive Growth of Pentecostalism. Video, 5:22. February 5. Available online: https://www.youtube.com/watch?v=0tGXBuYXpwk (accessed on 25 May 2018).

Brown, Andrew. 2009. Chinese Calvinism Flourishes. The Guardian. May 27. Available online: https://www.theguardian. com/commentisfree/andrewbrown/2009/may/27/china-calvin-christianity (accessed on 20 May 2018).

Carter, Gwendolen M. 1958. The Politics of Inequality: South Africa since 1948. New York: Praeger.

Chow, Alexander. 2014a. Calvinist Public Theology in Urban China Today. International Journal of Public Theology 8: 158-75. [CrossRef]

Chow, Alexander. 2014b. New Calvinism in China? Posted on May 22. Available online: http://www.cswc.div.ed. ac.uk/2014/05/new-calvinism-in-china/ (accessed on 15 May 2018).

Chow, Alexander. 2018. Chinese Public Theology. Generational Shift and Confucian Imagination in Chinese Christianity. Oxford: Oxford University Press.

Fällman, Fredrik. 2009. Chinese Christianity Is More than Calvin. The Guardian. June 6. Available online: https://www.theguardian.com/commentisfree/belief/2009/jun/05/religion (accessed on 15 May 2018).

Fällman, Fredrik. 2012. Calvin, Culture and Christ? Developments of Faith among Chinese Intellectuals. In Christianity in Contemporary China: Socio-Cultural Perspectives. Edited by Francis Khek Gee Lim. London and New York: Routledge, pp. 153-68.

Fulton, Brent. 2015. China's Urban Christians. A Light That Cannot Be Hidden. Eugene: Pickwick Publications.

Hansen, Collin. 2008. Young, Restless, Reformed. Wheaton: Crossway Books.

Hinsdale, Mason. 2017. China Is Israel's Fastest Growing Tourist Source Market, Growth Fueled by 'Religious History Buffs'. Jing Travel. October 13. Available online: https://jingtravel.com/china-is-israels-fastestgrowing-tourist-source-market-growth-fueled-by-religious-history-buffs/ (accessed on 20 May 2019).

Kang, Jie. 2016. House Church Christianity in China: From Rural Preachers to City Pastors. Basingstoke: Palgrave Macmillan.

Kingdon, Robert M., and Robert D. Linder, eds. 1970. Calvin and Calvinism: Sources of Democracy? Lexington: D. C. Heath.

Kuyper, Abraham. 1931. Lectures on Calvinism. Grand Rapids: Eerdmans.

$\mathrm{Ma}, \mathrm{Li}$, and Jin Li. 2018. Surviving the State, Remaking the Church. Eugene: Pickwick Publications.

Niebuhr, H. Richard. 1937. The Kingdom of God in America. Middletown: Wesleyan University Press. 